\title{
Promoting sexual well-being in social work education and practice.
}

Dr Sally Lee, Post-Doctoral Research Fellow, National Centre of Post Qualifying Social Work and Professional Practice, Bournemouth University.

lees@bournemouth.ac.uk

Professor Lee-Ann Fenge, Professor of Social Care and Deputy Director, National Centre of Post Qualifying Social Work and Professional Practice, Bournemouth University.

lfenge@bournemouth.ac.uk

Dr Bethan Collins, Lecturer in Occupational Therapy School of Health Sciences, University of Liverpool.

Bethan.Collins@liverpool.ac.uk

\begin{abstract}
This paper explores the importance of including sexual well-being within social work practice and education. Social workers often work with individuals for whom opportunities for sexual expression are limited and who face discriminatory attitudes. Sexual well-being is a global concern, and is particularly relevant considering international interest in the influence of notions of well-being on mental and physical health. Implementation of new social care policy in England, underpinned by the well-being principle, provides practitioners with the opportunity to explore what is meaningful to individual's well-being through personcentred approaches to practice. There is currently little coverage of sexual well-being within social work education, this means students and practitioners lack the knowledge and skills to challenge barriers. Promotion of the concept of sexual citizenship, with its associated rights and responsibilities, enables social workers to engage in rights focused practice. Sexual wellbeing is a sensitive subject and the social and personal barriers practitioners may experience in addressing this topic are explored.
\end{abstract}

\section{Key words: physical disability, sexual well-being, risk, social work education}

\section{Introduction}

Sexual well-being is one of the most significant aspects in life (Taylor, 2011), deeply connected to human well-being (Esmail, Munro, \& Gibson, 2007; Myers \& Milner, 2007; Dunk, 2007; Owens, 2015). This article argues that despite sexual well-being being a universal human concern with global relevance (WHO, 2012), there is currently limited coverage of sex in social work education and practice (Ballan, 2008; Sloane, 2014; Kattari \& Turner, 2017). Reflecting the location of the authors, focus is given to social work education and practice in the UK, however, reference is made throughout to the international context.

Enhancing well-being is core to international social work, highlighted in the final sentence of the International Federation of Social Work (IFSW) global definition:

Underpinned by theories of social work, social sciences, humanities and indigenous knowledges, social work engages people and structures to address life challenges and enhance wellbeing. (2014)

In England implementation of the Care Act (2014) introduces detriment to well-being as the criteria on which care and support needs are assessed. The Act reflects international interest in well-being and its impact on health (Bacon et al, 2010) and enables service users and practitioners to collaboratively explore what is meaningful to each individual, including 
sexual well-being. Practitioners need to be prepared and confident, to address the topic. This article aims to demonstrate that concern with well-being presents social workers with the opportunity to directly apply their interpersonal skills in the exploration of the meaning of well-being, in all its complexities, including sexual well-being.

This article emerges from doctoral research undertaken by the first author whilst working as a social worker with physically disabled adults. The research was initially prompted by enquiries from service users regarding barriers they experienced to gaining information, support with and opportunities for sexual expression. The service users' perceptions of barriers were corroborated through the research which was a qualitative, phenomenological exploration of the meaning of sexual well-being for disabled people. The research findings suggest approaches for how sexual well-being can be promoted within social work education and practice.

\section{Methodology}

The doctoral study, completed in 2016, was conducted with ethical approval gained through the Bournemouth University Ethics Committee and the relevant local authority research department. A phenomenological approach was taken to explore the meaning of sexual wellbeing for physically disabled people, and specifically the experience of physically disabled adults in receipt of local authority social care support. This small-scale project $(n=6)$ used unstructured interviews to focus on participants' lived experience and reflections on the meaning of sexual well-being. It was important to the research to enable participants with diverse disabilities, including non-verbal communication to participate, so tools including a symbols book were employed. Being sensitive to fatigue the number of interviews varied from one to three. Following consent, given either in written or verbal format according to the participant's disability, the interviews were recorded, transcribed verbatim, and then shared with the participants, reflecting the collaboration between researcher and participant in knowledge creation (Finlay, 2006). The aim was to provide rich descriptions of the constituent parts of sexual well-being to reveal essential general meaning structures of the phenomenon. Inductive analysis allowed units of meaning to emerge "like knots in the web of experience around which meaning is spun" (Van Manen, 1984, p. 59). These meaning units revealed insight into the participants' lived experience which indicate implications for social work practice and education explored in this article. These insights are now used to inform exploration of how sexual well-being can be considered in social work education and practice.

\section{The relevance of sexual well-being to social work education and practice}

Experience in research, social work practice and education indicate that sexual well-being is an outcome sought by some users of social services, but one that is difficult to achieve and rarely addressed in health and social care practice (Taylor, 2011). Research suggests that sexual activity remains an important part of life (Liddiard, 2013) and sexual satisfaction (Owens, 2015), intimacy (Shakespeare, 2000), love and sexual pleasure (Tepper, 2000; Sloane, 2014) are directly related to quality of life (Milligan \& Neufeldt, 2001).

According to Myers and Milner (2007, p. 59), who draw on Nusbaum and Rosenfield (2004), sex and good sexual health are components of well-being, including:

a link with the future through procreation;

a means of pleasure and procreation;

a sense of connection with others; 
a form of gentle, subtle or intense communication;

bring enhanced feelings of self-worth;

a contribution to self-identity

The connection between poor sexual health and well-being with poor health outcomes (Myers \& Milner, 2007; Sloane, 2014) makes addressing sexual well-being an important aspect of social work practice. In England, the Care Act 2014 tasks practitioners to use person centred approaches to explore the issues which impact upon individual well-being (Department of Health, 2017, section 1), including sexual well-being. However, without understanding the impact of sexual well-being on general health and well-being, and its intersection with health inequalities, discrimination and marginalisation of minority groups it can remain hidden as a social justice issue (Turner \& Crane, 2016). International social work practice focused on human well-being (IFSW, 2012, s2 and s4.1) requires practitioners to be prepared to explore diverse and sensitive topics, such as sex and sexual well-being, with openness, knowledge and confidence. This requires the creation of opportunities for reflective learning to explore personal attitudes to sex and sexuality (Sloane, 2014), along with learning about the impact of sexual well-being on physical and mental health during professional social work education.

Despite the consensus about the importance of sexual well-being to individual quality of life, there is limited literature specifically about sexual well-being within social work practice or education (with the exceptions of Myers \& Milner, 2007; Dunk, 2007; Bywaters \& Jones, 2007; Sloane, 2014; Kattari \& Turner, 2017). This may be due to the priority given in social work to the reduction of negative sexual experiences such as abuse and the promotion of antidiscriminatory practice related to sexual identity (Myers \& Milner, 2007). The apparent prioritisation of abusive sexual experiences within social work also relates to the primacy of risk management in practice (Ferguson 2007; Carr 2010) which may result in individuals being identified as sexually vulnerable, leading to restrictions on opportunities for sexual expression and development (Fish, 2016). This approach renders the responsibility for enabling sexual well-being either a health or an individual matter, not relevant to social work practice (Myers \& Milner, 2007). However, we argue that sexual well-being is relevant to social work practice as it relates to the fundamental causes of social need and positively contributes to well-being (WHO, 2012).

\section{Understanding sex and sexual well-being}

The inclusion of sexual well-being within social work education offers a specific lens through which insights into assumptions and values can be explored. For example, examining the contested meaning of sex (Myers \& Milner, 2007) is a route for students to gain insights into their personal value systems and world view, which in turn is required for person-centred and culturally competent practice (Ballan, 2008; Sloane, 2014). As Simpson (2012) suggests, exploration of well-being "provides a framework for a critically reflective and engaged practice... which is a feature of contemporary practice" (p. 622). Social work education supports critically reflective practice by encouraging students' ability to examine taken for granted truths (Fook, 2002). Educators' creation of safe spaces in which the tensions between social work values and cultural, political and religious traditions can be explored without fear or judgement, is crucial to student's development of the skills of critical reflection.

What is sex?

Debate concerns what constitutes a sexual act which is "limited only by the imagination and physical body" (Myers \& Milner, 2007, p. 8), yet, contrarily, is subject to legislative 
boundaries, state intervention and control regulating its permissible forms and location (Myers \& Milner, 2007; de Than, 2015).

Philosophy is drawn on to create moral overtones to traditional definitions of sex and correct sexual behaviour, using notions of normal and abnormal (Teichman \& Evans, 1991). The dominance of medical discourse influences human understanding of sexuality and sexual activity, contending that there are biological reasons for sexual preferences (Myers \& Milner, 2007). Sex can be defined with an essentialist emphasis as an "overpowering yet functionalist force in the individual that shapes personal and social life" (Stephen, 2002, p. 35). Foucault's work (1990) on the discourse of sexuality offers an alternative view, suggesting that sexuality is not a natural quality of the body but is the effect of historically specific power relations resulting in the dominance of certain forms of acceptable sexual expression.

People experience their sexual drive as a physical and emotional urge, yet the meaning attached to sex is moderated through socialisation including religious and cultural influences, constructed within a specific context and is therefore variable between different (Myers \& Milner, 2007). Sex, sexuality and sexual identities are also caught up in the mechanisms which maintain and construct the social order (Shildrick, 2007).

Social workers, like the public, gain knowledge about, and attitudes towards, sex and sexuality, from personal experience, sex education and cultural representations, all of which may be limited and unrealistic (Sloane, 2014). Without sexual well-being being part of reflexive professional education, social workers could potentially contribute to oppressive practices reflecting normative attitudes to sexuality, due to lack of knowledge or discomfort in advocating for sexual citizenship. Schaub et al (2016) found more than $90 \%$ of respondents in their research with practicing social workers in the UK had received no sexuality-specific training. This research was initiated by service users seeking support with sexual well-being, and it is hoped that the findings now can provide some guidance for education of social workers in issues of sexual well-being for adults with physical disability.

\section{Sex and the law}

In the UK, the Sexual Offences Act 2003 defines criminal offences stating that sexual activity with consent is generally lawful (de Than, 2015). To give consent one must have capacity as defined in the Mental Capacity Act 2005 (MCA). Assessors have a duty to undertake all practicable steps to enable communication (MCA, section1(3)), and by doing so, to promote the human rights of the individual to make decisions around their sexual expression and to participate in sexual activities of their choosing. This is especially important when disability affects communication and social workers must balance their duty of care to assess and report risk, but also promote rights. Excessive safeguarding can breach the duty of care if it prevents the person exercising choice and control. For those who have communication difficulties, but wish to engage in sexual activity, the law makes this balancing of the duties of care problematic as the Sexual Offences Act 2003 potentially criminalises even longstanding relationships where one partner has lost the capacity to consent.

Case law has grappled with the issue of consent to sexual activity (Series, 2014). Debate concerns whether the capacity to consent requires:

1. Consent to sex in general or at a particular time, place and with a specific person.

2. The ability to understand on a simple level

(a) the mechanics of the act; 
(b) that there are health risks involved, particularly the acquisition of sexually transmitted infections;

(c) (if relevant to them) that sex between a man and a woman may result in the woman becoming pregnant

3. The ability to use and weigh the information. (Series, 2014)

In addition to lack of clarity regarding consent, fear of criminal liability for supporting people with their sexual expression (for example, assisting them in making appointments with sex workers) is very common in the health and social care professions (de Than, 2015). This fear is often due to misunderstanding of the law around the purchasing of sex and whether providing assistance with sexual activity by a third person (for example, a facilitator, personal assistant or carer) makes the location a public place, and therefore illegal.

Without clarity in case law and professional codes of practice, as well as inclusion in social work curriculum, this is a potentially problematic issue for practitioners supporting service users who require assistance to access sexual services, and requires ways of assisting which do not breach professional standards.

\section{Sexual well-being}

The term 'well-being', rather than 'health', distinguishes the topic from medical matters such as fertility or sexually transmitted diseases. However, The World Health Organisation's holistic definition of sexual health encapsulates the multi-faceted nature of sexual well-being which includes mind, body and environment (Author citation):

Sexual health is a state of physical, emotional, mental, and social well-being in relation to sexuality; it is not merely the absence of disease, dysfunction, or infirmity. Sexual health requires a positive and respectful approach to sexuality and sexual relationships, as well as the possibility of having pleasurable and safe sexual experiences, free of coercion, discrimination, and violence. Sexuality is a central aspect of being human throughout life and encompasses sex, gender identities and roles, sexual orientation, eroticism, pleasure, intimacy, and reproduction. (2012, p. 6).

Like sex, well-being is a contested term, a social and cultural construction defined by the agent employing it (Ereaut \& Whiting, 2008). The meaning of well-being used in this work relates to how people experience their lives, specifically their sexual selves. It is not only the absence of problems or the presence of happiness but concerns the person's experience of self-actualisation, social integration, expectation and equality of potential - mind, body and environment (Local Government Improvement and Development Report, 2010). This multidomain conceptualisation of well-being relates to the definition of well-being within the Care Act 2014 which identifies nine domains, including personal dignity, physical and mental health and emotional wellbeing, protection from abuse and neglect, control by the individual over day-to-day life and domestic, family and personal life (Department of Health, 2017, $1.5)$. 
Sexual well-being is central to social work practice focused on human rights and well-being, however, there are barriers to practitioner engagement and possible ways to overcome these barriers.

\section{Barriers to practitioner engagement with sexual well-being}

Sexual well-being is a sensitive topic however, social workers have a unique role and their preparedness to discuss difficult and sensitive subjects is a professional strength (Bywaters \& Ungar, 2010). Barriers to discussing sexual well-being include fear of the potential for legal or safeguarding repercussions (de Than, 2015), which negatively changes the relationship between social worker and service user, making partnership extremely challenging (Parton \& O'Byrne, 2000). Further barriers involve fear of not knowing what to do and inadequate or absent training and policy (Dyer \& das Nair, 2013).

\section{Risk aversion}

The concept of risk is used in different ways, including contradictions in agencies making formal affirmations of risk enablement whilst demonstrating organisational risk avoidance (Furedi, 2011). The Human Rights Act 1998, provides legal protection from any actions by public authorities which might harm citizens (including risk aversion which restricts life opportunities), whilst the International Convention on the Rights of Persons with Disabilities (CRPD) (2008) requires the promotion of fair and equal treatment of disabled people. Article 19, CPRD, requires governments to take action to facilitate disabled people's full inclusion and participation in society and the community, and to fully enjoy this right. In addition, the Equality Act 2010 requires that arrangements are made to remove or avoid a substantial disadvantage within a provision, service or practice which could be used to argue for education, information or the provision of equipment to aid sexual well-being.

Service user views have received little research and policy attention (Furedi, 2011), and risk averse policy does not reflect the views of service users who want greater control over their routine, access to rights, order and sensitive care. Truly person-centred practice embraces risk enablement, encouraging service users to achieve sexual well-being (Bywaters \& Jones, 2007), but this creates anxiety within a culture of risk aversion. Social work education needs to provide safe spaces where students can openly explore the personal and professional dilemmas occurring where human rights intersect with the duty to protect from harm. The focus on outcomes within recent adult safeguarding policy expressed in England and Wales by Making Safeguarding Personal (Local Government Association, 2014) and the Care Act 2014, provides an alternative framework for this exploration as it moves away from a protectionist to an enabling stance, for example, in reference to sexual well-being this could be thinking about ways of supporting someone in identifying and managing risks associated with their sexual expression.

The safeguarding outcomes in the English Care Act concern the promotion of well-being and prevention of abuse and neglect to ensure safety and well-being. This may cause tension between service user and social worker if the outcomes people may wish involve risk. Some sections of the population are labelled as particularly at risk, including disabled and older people (Hollomotz, 2010), making risk enablement for these populations particularly challenging for practitioners who may fear hostility from the individual's family and community. 
Fear of risk enablement and risk aversion are barriers to social work addressing sexual wellbeing not only because it concerns the risk experienced by service users and but also risk to social workers themselves (Schraer, 2014). Front-line staff can be fearful of something happening for which they may be personally accountable (Faulkner, 2012).

The relationship between risk management and risk enablement is particularly relevant to the promotion of sexual well-being in social work because managing risk is part of enabling people to live full lives (The College of Social Work, 2013). Managing means balancing rights and risks; in relation to sexual well-being: this can be the right to a private life, but also the right to protection if a private life is harmful (Sin Hoong, Hedges, Cook, Mguni, \& Comber, 2011). Social workers make challenging judgements, being careful not to over risk manage, thereby effectively limiting social inclusion and life chances of service users. They need to empower service users to take the risks which enhance their lives, including activities which enable sexual well-being (de Than, 2015).

Empowerment is an essential part of the social work role (Ife, 2001) and should include sexual rights. Promoting notions of sexual citizenship, which involve rights and responsibilities, as well as well-being, provides the conceptual route through which the promotion of sexual well-being in social work practice can occur. Basing practice on promotion of sexual citizenship can counter disempowering practices illustrated by Lord Justice Munby in the 2007 case of MM, who had been stopped from having a sexual relationship by her local authority:

Physical health and safety can sometimes be bought at too high a price in happiness and emotional welfare. What good is making someone safer if it merely makes them miserable? None at all! (cited in de Than, 2015, p. 87).

How sexual citizenship is the basis for empowering practice is explored in the following section.

\section{Using sexual citizenship as the means to focus on sexual well-being in social work}

Social work is concerned with human rights (BASW, 2012); social care legislation is informed by and built on the United Nations Universal Declaration of Human Rights (1948), and the Human Rights Act 1998 in the UK. The notion of citizenship draws on human rights with citizenship giving access to justice, the right to a private life and to full participation in society with access to social opportunities, work, education and recreation. Sexual citizenship (Weeks, 1998) promotes rights specifically connected to sexual well-being and challenges the exclusion from opportunities for sexual expression experienced by marginalised people (Fritsch, 2016). This is grounded in principles of human sexual rights which apply existing human rights to sexuality and sexual health (WHO, 2012). Kanguade (2010) describes how sexual rights involve three dimensions:

- demand for control over bodies, feelings and relationships;

- $\quad$ demand for access, representations, relationships and public spaces;

demand for choice about identities, lifestyles and experience. (pp. 210-211)

For practice to advance human rights, it is not enough to avoid oppression, but rather it is necessary to promote rights, meaning actively challenging injustice and inequality. Well- 
informed attitudes and willingness to advance inclusive citizenship are significant to the achievement of sexual well-being (de Than, 2015). Fundamental human rights concerning relationships are stated in law: article 8 of the Human Rights Act 1998 states that everyone has the right to respect for their private life and family life; the European Court of Human Rights holds that this protects sexual autonomy, confidentiality, dignity, forming and maintaining personal relationships and allowing them to develop (de Than, 2015).

Human rights are made more specific for disabled people within the International Convention on the Rights of Persons with Disabilities (2008). Article 19, for example, requires governments to act to facilitate disabled people's "full enjoyment" of this right and their "full inclusion and participation in the community" (Parker and Clements, 2008, p. 509). Legal entitlement is clear: people have the right to a private life including their sexual expression and to have relationships of their choice; social work seeks to promote human rights and this should include sexual citizenship. To meet the responsibility of the empowerment of people, social workers require knowledge about how, why and to whom abuse occurs and the factors which aid prevention. As social work practice requires knowledge of the implications of these human rights, this clearly needs to be part of social work education.

\section{Education for professionals}

The difficulty practitioners may experience in discussing sexual matters is not a reason for the topic to be avoided. Practice which fails to address issues which matter to people is dehumanising (Galvin \& Todres, 2013). Social workers have privileged access to individuals and their support networks at times of "psycho-social transition" and encounters may concern intimate or emotional subjects (Jones, 2014, p. 495). As social work practice does not avoid other sensitive topics, avoidance of sexual well-being cannot be justified. Responsibility for the "sexual self" is central in contemporary social life and "each citizen must now negotiate the sexed aspect of their self" (Dunk, 2007, p. 135). To remain relevant to contemporary life, knowledge of sexual issues is vital to the practice and education of social workers and is relevant to all client groups (Author citation). Social workers' codes of ethical practice task them to advocate for the rights of the people with whom they work (IFSW, 2012), including their sexual rights (de Than, 2015). The IFSW Statement of Ethical Principles (2012) underpins national codes for ethical practice adapted to suit the specific needs of individual countries. The IFSW website provides links to the various codes, including to the British Association of Social Workers code of practice (2012).

To overcome barriers to engagement in the topic of sexual well-being, practitioners need to feel confident in their knowledge, skills and values. "Social workers need to be comfortable with their own sexuality, check their sexual knowledge and develop a sexual language before talking to service users about such matters" (Myers and Miler, 2007, p. 67). Professionals' uncertainty about whose job it is to address sexuality can leave people without crucial information, it is everyone's job to at least feel comfortable with the subject to enable service users to discuss it with whomever they feel most comfortable (Dunk, 2007).

This paper has suggested that sexual well-being is an essential aspect of individual's wellbeing and therefore should be part of social work education and practice. Responding to diverse sources of knowledge required for social work, including service user knowledge, practice wisdom and research (RiPfA, 2013), and considering the importance and complexities of sex and sexual well-being and the barriers to addressing sexual well-being in practice means an effective method to introduce sexual well-being into education is needed. Learning about a sensitive topic must be accessible and emotionally and intellectually 
engaging in ways which invite curiosity and empathetic connection. This relates to the power of research focused on lived experience, it is service users' accounts of their experience which are so evocative, often provoking emotional responses and prompts to action to address social injustice (Milligan \& Neufeldt, 2001). Representation of knowledge in humanly sensitive ways creates embodied relational understanding; knowledge for "the head, hand and heart" (Galvin \& Todres, 2013, p. 150). Interactive approaches which start with the learner's own experience and stimulate discussion, such as exercises around the barriers practitioner's face in discussing sex, asking learners to consider ways of overcoming the barriers enhances reflective learning.

The participants of the study from which this article emerges, provide key information about four qualities they require from practitioners to enhance practice around sexual well-being. These qualities are reflected in the wider literature:

1. Non-judgmental attitude; participants felt this was often absent in their dealings with practitioners despite it being fundamental to social work values (BASW, 2012; HCPC, 2017). Oliver and Sapey's (2006) critique of social work with disabled people, states that practitioners often perpetuate the negative social discourse regarding disability, a point reiterated elsewhere in the literature, for example Katari \& Turner, 2017.

2. Knowledge about sexual well-being and the intersection of disability and sexual expression, health and well-being. The participants expressed disappointment with the lack of knowledge they had encountered amongst practitioners, a point noted in the literature, including Katari \& Turner, 2017, Sloane, 2014, Liddiard, 2013, Myers \& Milner, 2007, Bywaters and Jones, 2007, and Shakespeare, 2004.

3. Openness and willingness to discuss sensitive issues, including sexual well-being. Social work is a profession willing to discuss sensitive issues (Bywaters and Ungar, 2010), however, as discussed earlier in this article, practitioners can be reluctant to broach the subject of sexual well-being.

4. Trust; the participants stated that trust, based on the presence of the preceding three qualities is required when exploring issues around sexual well-being with social work practitioners. Core to social work is establishing and maintaining relationships founded on trust and respect (HCPC, 2017; BASW, 2012, Ruch et al, 2010). The sensitive nature of the issues which matter to people, such as sexual well-being, highlights the important role of trust in being able to offer appropriate support.

These qualities do not represent a challenge to social work education and practice which makes the inclusion of sexual well-being too difficult, instead they relate to fundamental social work skills and core expectations of good practice stated within international codes of practice (IFSW, 2012; BASW, 2012). This suggests that the inclusion of sexual well-being within social work practice requires an enhancement, rather than change, to current education and practice to include examination of attitudes, knowledge, openness and trust in practice in relation to sexual well-being. Returning to an earlier point, this requires educators to create safe spaces in which critical reflection can occur (Sloane, 2014).

\section{Conclusion}


This paper argues the importance of enabling the inclusion of sexual well-being in social work practice and education. However, sex is a sensitive topic, overlaid with cultural and social meaning, therefore for social workers to be able to address the topic with knowledge and confidence, sexual well-being needs to become part of social workers learning. This learning needs to include knowledge about the intersection between sexual well-being and the traditions, norms and expectations which shape human experience. It means creating learning for "the head, hand and heart" (Galvin \& Todres, 2013, p. 5) which incorporates research around concepts of sex and sexual well-being (for the head), practical knowledge to enable the sexual expression of marginalised people (for the hand - for example understanding the impact of different disabilities on the senses and how this might relate to sexual activity) and encouragement of genuinely person focused practice based on fundamental social work values of empathy, respect and compassion (for the heart). Adopting such a positive and proactive approach could balance the general focus in practice on negative sexual experiences.

The next stage of this work will build on the findings from the doctoral work, specifically to investigate the best way to raise awareness of sexual well-being issues among health and social care workers and subsequently to co-produce a learning tool with participants, the nature of which will be devised by the collective groups. The aim is not to train workers as sexual therapists but to make them sexual well-being enablers, able to discuss sexual concerns, offer information and direction to further information and resources to support sexual citizenship. For social work educators, this means that they too need to be able to engage with the topic meaningfully, able to explore their own values and beliefs, confident in their knowledge. This requires a curriculum which includes sexual well-being, informed by research based evidence concerning the lived experience of sexual well-being as well as the complexities of sexual well-being resulting from the cultural and social understanding of sexual issues and the macro level influences on every day experience of sex.

\section{References}

Bacon, N., Brophy, M., Mguni, N., Mulgan, G. \& Shandro, A., 2010. The State of Happiness: Can public policy shape people's well-being and resilience? London: The Young Foundation. Retrieved from https://youngfoundation.org/wp-content/uploads/2012/10/The-State-ofHappiness.pdf

Ballan, M. (2008). Disability and sexuality within social work education in the USA and Canada: The social model of disability as a lens for practice. Social Work Education, 27, 194-202. doi: 10.1080/02615470701709675

British Association of Social Workers. (2012). Code of Ethics for Social Work - Statement of Principles. Birmingham, BASW. Retrieved from http://cdn.basw.co.uk/upload/basw_112315-7.pdf.

Bywaters, J., \& Jones, R. (2007). Sexuality and Social Work. Exeter: Learning Matters. 
Bywaters, P., \& Ungar, M. (2010). Health and well-being. In I. Shaw, K. Briar-Lawson, J. Orme, \& R. Ruckdeschel (Eds.), The Sage handbook of social work research (pp. 392-405). London: Sage.

Care Act 2014, c. 23 (2014). London: The Stationery Office.

Carr, S. (2010). Enabling risk, ensuring safety: Self-directed support and personal budgets (Report No. 36). Retrieved from http//www.scie.org.uk/publications/reports/report36/

Department of Health. (2012). The new public health role of local authorities. London: The Stationery Office. Retrieved from http://www.gov.uk/government/uploads/system/uploads/attachment_data/file/213009/Publichealth-role-of-local-authorities-factsheet.pdf.

Department of Health. (2017). Care and Support Statutory Guidance Issued under the Care Act 2014 (updated August 2017). London: The Stationery Office. Retrieved from http://www.gov.uk/guidance/care-and-support-statutory-guidance.

de Than, C. (2015). Sex, disability and human rights. In: T. Owens (Ed.), Supporting disabled people with their sexual lives (pp. 86-103). London: Jessica Kingsley.

Disability Discrimination Act, c. 50. London: The Stationery Office.

Dunk, P. (2007). Everyday sexuality and social work: Locating sexuality in professional practice and education. Social Work and Society, 5, 135-142. Retrieved from http://www.socwork.net/sws/article/view/112/401

Dyer, K., \& das Nair, R. (2013). Why don't healthcare professionals talk about sex? A systematic review of recent qualitative studies conducted in the United Kingdom. Journal of Sexual Medicine, 10, 2658-2670. doi: 10.1111/j.1743-6109.2012.02856.x

Equality Act 2010, c. 15. London: The Stationery Office.

Ereaut, G., \& Whiting, R. (2008). What do we mean by well-being? And why might it matter? (Research Report No. DCSF-RW073). London: Department for Children, Schools and Families. Retrieved from: http://dera.ioe.ac.uk/8572/1/dcsf-rw073\%20v2.pdf

Esmail, S., Munro, B., \& Gibson, N. (2007). Couple's Experience with Multiple Sclerosis in the Context of their Sexual Relationship. Sexuality and Disability. 25,163-177. doi: $10.1037 / \mathrm{a} 0023362$

Faulkner, A. (2012). The right to take risks. The Journal of Adult Protection. 14, 287-296. Doi: $10.1108 / 14668201211286066$

Ferguson, I. (2007). Increasing user choice or privatizing risk? The antinomies of personalization. British Journal of Social Work, 37, 387-403. doi: https://doi.org/10.1093/bjsw/bcm016

Finlay, L. (2006). Dancing between embodied empathy and phenomenological reflection. Indo-Pacific Journal of Phenomenology, 6, 1-11. doi:10.1080/20797222.2006.11433930

Fish, R. (2016). "They've said I'm vulnerable with men": Doing sexuality on locked wards. Sexualities, 19, 641-658. doi:10.1177/1363460715620574

Fook, J. (2002). Social work: Critical theory and practice. London: Sage.

Foucault, M. (1990). The history of sexuality: The will to know (6th ed.). London: Penguin. 
Fritsch E. (2016). Disability and sex work: Developing affinities through decriminalization. Disability \& Society, 31, 84-99. doi: 10.1080/09687599.2016.1139488

Furedi, F. (2011). Changing societal attitudes and regulatory responses to risk taking in adult care. York: Joseph Rowntree Foundation.

Galvin, K. \& Todres, L. (2013). Caring and well-being: A lifeworld approach. Abingdon: Routledge.

Health \& Care Professions Council. (2017). Standards of Proficiency for social workers in England. Retrieved from http://www.hpc-

uk.org/assets/documents/10003B08Standardsofproficiency-SocialworkersinEngland.pdf

Hollomotz, A. (2010). Sexual "vulnerability" of people with learning difficulties: A selffulfilling prophecy. In R. Shuttleworth, \& T. Sanders, T. (Eds.), Sex \& Disability: Politics, Identity and Access (pp. 21-40). Leeds: The Disability Press.

Human Rights Act 1998, c. 42. London: The Stationery Office.

Ife, J. (2001). Human rights and social work: Towards rights-based practice. Cambridge: Cambridge University Press.

International Federation of Social Work. (2012). Statement of Ethical Principles. Retrieved from http://ifsw.org/policies/statement-of-ethical-principles/

International Federation of Social Work. (2014). Global Definition of Social Work. Retrieved from http://ifsw.org/policies/definition-of-social-work/

Jones, R. (2014). The best of times, the worst of times: Social work and its moment. British Journal of Social Work, 44, 485-502. doi: https://doi.org/10.1093/bjsw/bcs157

Kanguade, G. (2010). Advancing sexual health of persons with disabilities through sexual rights: The challenge. In R. Shuttleworth, T. \& Sanders, T. (Eds.), Sex and Disability: Politics, Identity and Access (pp. 197-215). Leeds: The Disability Press.

Kattari, K., \& Turner, G. (2017). Examining more inclusive approaches to social work, physical disability, and sexuality. Journal of Social Work in Disability \& Rehabilitation, 16(1), 38-53. doi: 10.1080/1536710X.2017.1260517

Liddiard, K. (2013). Reflections on the process of researching disabled people's sex lives. Sociological Research Online, 18(3), 10. Retrieved from http://www.socresonline.org.uk/18/3/10.html

Local Government Association. (2014). Making Safeguarding Personal. London: Local Government Association.

Local Government Improvement and Development. (2010). The role of local government in promoting wellbeing: Healthy communities programme. Retrieved from http://b.3cdn.net/nefoundation/bb8366694aa033e578_vvm6bfv3t.pdf

McKitterick, B. (2012). Supervision. Maidenhead: Open University Press.

Mental Capacity Act 2005, c. 9. London: The Stationery Office.

Milligan, M., \& Neufeldt, A. (2001). The myth of asexuality: A survey of social and empirical evidence. Sexuality and Disability, 19, 91-109. doi: 10.1023/A:1010621705591 
Myers, S., \& Milner, J. (2007). Sexual Issues in Social Work. Bristol: British Association of Social Work.

NHS and Community Care Act 1990, c. 19. London: The Stationery Office.

Nusbaum, M., \& Rosenfeld, J. A. (2004). Sexual health across the lifecycle: A practical guide for clinicians. Cambridge: Cambridge University Press.

Owens, T. (2015). Supporting disabled people with their sexual lives. London: Jessica Kingsley.

Parker, C., \& Clements, L. (2008). The UN Convention on the rights of persons with disabilities: A new right to independent living? European Human Rights Law Review, 4, $508-524$.

Parton, N., \& O’Byrne, P. (2000). Constructive social work: Towards a new practice. Basingstoke: Palgrave.

Research in Practice for Adults. (2013). Finding, appraising and using evidence in Practice. Professional Capabilities Framework: Evidence-Informed Practice. Dartington: RiPFA. Retrieved from https://www.ripfa.org.uk/resources/publications/practice-tools-andguides/professional-capabilities-framework-evidenceinformed-practice-folder-and-first-setof-cards-for-experienced-practitioners-2013

Ruch, G., Turney, D. \& Ward, A. eds. (2010) Relationship-based Social Work: Getting to the Heart of Practice. London: Jessica Kingsley.

Schaub, J., Willis, P., \& Dunk-West. (2017). Accounting for self, sex and sexuality in UK social workers' knowledge base: Findings from an exploratory study. British Journal of Social Work, 47, 427-446. doi: 10.1093/bjsw/bcw015

Series, L. (2014, January 24). Framing the test of capacity to consent to sex [Web log post]. Retrieved from http://thesmallplaces.blogspot.co.uk/2014/01/framing-test-of-capacity-toconsent-to.html

Shakespeare, T. (2000). Disabled sexuality: Toward rights and recognition. Sexuality and Disability, 18, 159-166. doi: 10.1023/A:1026409613684

Shildrick, M. (2007). Contested pleasures: The sociopolitical economy of disability and sexuality. Sexuality Research \& Social Policy Journal of NSRC, 4, 53-66. doi: 10.1525/srsp.2007.4.1.53

Simpson, G. (2012). Developing wellbeing as a critical tool in social work education: An example from the field of learning disability. Social Work Education, 31, 622-63. doi: $10.1080 / 02615479.2011 .605619$

Sin Hoong, C., Hedges, A., Cook, C., Mguni, N., \& Comber, N. (2011). Adult protection and effective action in tackling violence and hostility against disabled people: Some tensions and challenges. The Journal of Adult Protection, 13, 63-74.

doi.org/10.1108/14668201111139718 
Sloane, H. (2014). Tales of a Reluctant Sex Radical: Barriers to Teaching the Importance of Pleasure for Wellbeing. Sexuality \& Disability. 32:453-467. Doi: 10.1007/s11195-014-93815

Stephen, K. (2002). Sexualised bodies. In M. Evans, \& E. Lee (Eds.), Real bodies: A sociological introduction. Palgrave: Basingstoke.

Taylor, B. (2011). The impact of assistive equipment on intimacy and sexual expression. British Journal of Occupational Therapy, 74, 435-442. doi: 10.4276/030802211X13153015305637

Teichman, J., \& Evans, K. (1991). Philosophy: a beginners guide. Oxford: Blackwell.

Tepper, M. (2000). Sexuality and disability: The missing discourse of pleasure. Sexuality and Disability, 18, 283-290. doi: 10.1023/A:1005698311392

The College of Social Work. (2013). Social work with adults: What does the future hold? Summit at The College of Social Work, 17 December 2013. Retrieved from www.basw.co.uk/resources/tcsw/Social\%20work\%20with\%20adults\%20$\% 20$ what $\% 20$ does $\% 20$ the $\% 20$ future\%20hold.pdf

Turner, G., \& Crane, B. (2016). Sexually silenced no more, adults with learning disabilities speak up: A call to action for social work to frame sexual voice as a social justice issue. British Journal of Social Work, 46, 2300-2317. doi: 10.1093/bjsw/bcw133

United Nations. (2008). Convention on the Rights of Persons with Disabilities. Retrieved from https://www.un.org/development/desa/disabilities/convention-on-the-rights-of-personswith-disabilities.html.

Van Manen, M. (1984). Practicing phenomenological writing. Phenomenology and Pedagogy. 2, 36-68. Weeks, J. (1998). The sexual citizen. Theory, Culture and Society, 15, 35-52. doi: $10.1177 / 0263276498015003003$

World Health Organisation. (2012) Reproductive Health, Sexual Health. Retrieved from www.who.int/reproductivehealth/topics/gender_rights/sexual_health/en/ 